\title{
KARAKTERISTISASI DAN PROFIL BIODEGRADASI MATERIAL BIOKOMPOSIT BOVINE HIDROKSIAPATIT (BHA)/AMPAS KOPI/SHELLAC
}

\author{
Taufik Hidayat $^{1}$, Joko Triyono ${ }^{2}$, Abu Masykur ${ }^{2}$ \\ ${ }^{1}$ Teknik Mesin - Universitas Sebelas Maret \\ ${ }^{2}$ Kimia - Universitas Sebelas Maret \\ e-mail address: Taufik_2904@yahoo.com (Taufik Hidayat), jokotri5528@gmail.com (Joko Triyono), \\ abu.masykur@gmail.com (Abu Masykur)
}

\begin{tabular}{|c|c|}
\hline Keywords: & Abstract: \\
\hline $\begin{array}{l}\text { Biodegradation, Bovine } \\
\text { Hydrroxyapatite, FTIR, } \\
\text { Porosity, SEM, XRD. }\end{array}$ & $\begin{array}{l}\text { The incidence of fractures in Indonesia is quite high so it needs } \\
\text { biomaterials in the field of health that is economical and environmentally } \\
\text { friendly. Bovine bone waste can be used for grafting, repairing, } \\
\text { replenishing or replacing bones and restoring dental tissue. The purpose of } \\
\text { this research is to determine whether the content of the coffee grounds and } \\
\text { shellac will disappear after the sintering process, and how the effects of } \\
\text { coffee grounds on the porosity and degradation rate of BHA biocomposite } \\
\text { materials. This research uses heating method of calcination and sintering. } \\
\text { Based on the analysis of test data conducted, it was concluded that SEM } \\
\text { EDX observation shows the presence of inorganic elements of Ca and } P \\
\text { with high intensity and Na, Mg, O and C with low intensity. Observation of } \\
\text { XRD diffraction pattern shows } 2 \theta \text { values of the sample according to the } \\
\text { standard diffraction pattern of HA JCPDS } 9-432 \text {. FTIR functional group } \\
\text { analysis showed no major peak points other than phosphate functional } \\
\left.\left.\text { groups (PO }{ }_{4}^{3-}\right) \text {, carbonates (CO }{ }^{2-}\right) \text { and hydroxyl }\left(O H^{-}\right) \text {. From these three } \\
\text { observations indicate that the content of coffee and shellac dregs has } \\
\text { disappeared completely when the sintering process and leaving only the } \\
\text { content of BHA and the more mixture of coffee dregs used will decrease the } \\
\text { density value and increase the number of porus and accelerate the } \\
\text { degradation rate. }\end{array}$ \\
\hline
\end{tabular}

\section{PENDAHULUAN}

Hydroxyapatite (HA) merupakan biomaterial dari komponen utama jaringan tulang dan gigi. HA dapat diperoleh dari tulang sapi (bovine hydroxyapatite) dan telah secara luas dipergunakan untuk mencangkok, memperbaiki, mengisi, atau mengganti tulang serta pemulihan jaringan gigi karena biokompabilitas yang sangat baik dengan jaringan keras, bioaktivitas merekonstruksi ulang jaringan tulang yang telah rusak dan juga di dalam jaringan yang lunak [1]. Biocompatibility berhubungan dengan beberapa karakteristik dari biomaterial yang menunjukkan apakah material tersebut dapat diterima di dalam tubuh manusia seperti tidak mengandung racun, tidak bersifat carciogenic, tidak menyebabkan alergi, dan tidak immunogenic [2]. Pengisi tulang (bone filler) juga harus bersifat biodegradable yaitu kemampuan material untuk terdegradasi seiring dengan tumbuhnya tulang manusia secara alami. Degradasi dari material adalah aspek yang sangat penting untuk dipertimbangkan ketika material tersebut dipakai untuk kepentingan medis, karena kemampuannya untuk difungsikan pada suatu aplikasi tergantung pada lamanya waktu yang dibutuhkan untuk menyimpannya di dalam tubuh. Proses biodegradasi biomaterial dan kecepatan degradasi di dalam sebuah organisme berhubungan dengan karakteristik dari material dan tempat di dalam tubuh yang digunakan [3].

Berdasarkan latar belakang tersebut masih diperlukan penelitian mengenai hidroksiapatit tulang sapi (BHA) dengan metode serbuk yang dicampur ampas kopi dan dilapisi shellac. Penggunaan ampas kopi pada penelitian ini dikarenakan pada saat proses sintering ampas kopi akan bereaksi dengan oksigen $\mathrm{O}_{2}$ dan berubah menjadi fasa gas yang menyebabkan serbuk dari ampas kopi akan menghilang dan membentuk struktur berpori pada bone filler. Struktur berpori tersebut berguna sebagai jalan sel-sel yang ada pada tulang agar dapat menyatu, dan memungkinkan dalam pertumbuhan tulang. Struktur berpori akan mengurangi kekuatan dari bone filler tetapi akan mempercepat laju degradasi.

Hasil dari penelitian diharapkan dapat digunakan untuk bahan pengisi tulang (bone filler) dan dapat diimplementasikan terhadap penderita penyakit tulang dan gigi.

\section{METODOLOGI PENELITIAN Bahan}


Bahan yang digunakan dalam penelitian ini adalah hidroksiapatit dari tulang sapi bagian femur (BHA), ampas kopi, dan larutan shellac. Ampas kopi digunakan sebagai material pembentuk porus dan larutan shellac digunakan sebagai pengikat antar serbuk BHA.

\section{Proses Persiapan}

BHA diperoleh dari serbuk tulang sapi bagian femur yang dijadikan serbuk dengan ukuran $250 \mu \mathrm{m}$ dan kemudian dikalsinasi dengan suhu $900^{\circ} \mathrm{C}$. Ampas kopi yang digunakan adalah ampas kopi yang telah dibersihkan dari kotoran dan ketika dicuci sudah tidak memiliki warna. Larutan shellac didapatkan dari campuran antara sekresi kutu lak dan ethanol 97\% dengan perbandingan 1:10. Selanjutnya, BHA dicampur ampas kopi dengan perbandingan volume BHA dan ampas kopi berturut-turut yaitu 70/30, 60/40, 50/50, 40/60, dan 30/70, kemudian BHA/ampas kopi dicampur dengan $1 \mathrm{ml}$ larutan shellac dan diaduk menggunakan magnetic stirrer dengan kecepatan $200 \mathrm{rpm}$. Serbuk yang sudah tercampur dikompaksi dengan beban $974 \mathrm{MPa}$ dengan penahanan 5 menit agar menjadi bentuk tablet dengan ukuran diameter $13 \mathrm{~mm}$ dan tebal $3 \mathrm{~mm}$. Spesimen tersebut kemudian disinter dengan suhu $1000^{\circ} \mathrm{C}$ untuk mengikat antar serbuk BHA dan menghilangkan kandungan dari ampas kopi dan shellac.

\section{Pengamatan}

Pengamatan yang dilakukan pada spesimen BHA/ampas kopi/shellac adalah sebagai berikut:

a. Pengujian densitas dan porositas

Pengujian densitas dilakukan dengan mengacu pada hukum Archimedes. Pengujian dilakukan dengan menimbang berat sampel saat di udara dan berat sampel saat di dalam air. Pengujian porositas didapat dari perhitungan densitas aktual dan teoritis.

b. Pengamatan SEM

Pengamatan ini meliputi pengambilan foto SEM untuk mengetahui bentuk porus dan SEM EDX untuk mengetahui kandungan yang ada pada sampel uji BHA/ampas kopi/shellac.

c. Pengamatan biodegradasi

Pengamatan biodegradasi dilakukan dengan menghitung penurunan berat sampel berbentuk tablet selama 2 bulan di dalam botol kecil berisi $20 \mathrm{ml}$ PBS dan diinkubasi pada $37^{\circ} \mathrm{C}$ dengan penggantian larutan dan pengambilan data setiap 7 hari sekali. Pengambilan data dilakukan dengan mengeringkan spesimen di dalam mesin oven dengan suhu $130^{\circ} \mathrm{C}$ dan penahanan temperatur selama 1 jam.

d. Pengamatan pola difraksi XRD

Pengamatan pola difraksi XRD ditunjukkan dengan $30 \mathrm{kV}, 30 \mathrm{~mA}$ dengan target $\mathrm{Cu}$. Pengujian ini meliputi pengambilan data spesimen dalam bentuk serbuk untuk mengetahui struktur kristal, fasa dan derajat kristalinitas. e. Pengamatan gugus fungsi dengan FTIR

Pengamatan ini meliputi pengambilan data spesimen dalam bentuk serbuk untuk mengetahui gugus fungsi yang terkandung dalam spesimen.

\section{HASIL DAN PEMBAHASAN Hasil pengujian densitas}

Hasil pengujian densitas menunjukkan perbandingan densitas aktual dan densitas teori. Nilai densitas diperoleh dari sampel BHA/ampas kopi/shellac setelah proses sintering. Hasil pengujian densitas dapat dilihat pada Gambar 1.

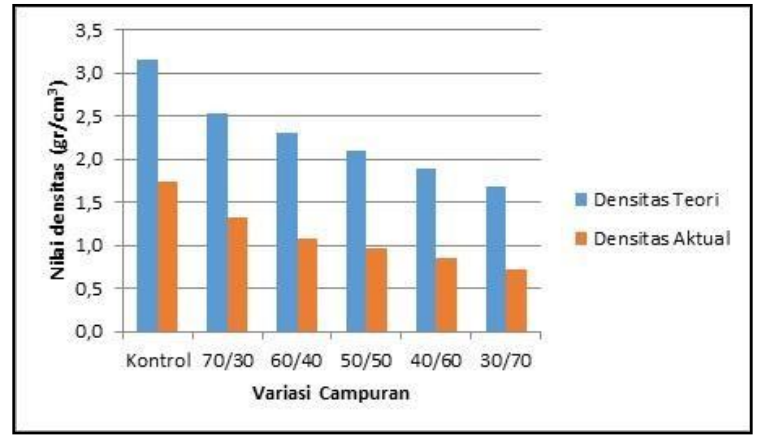

Gambar 1 Hasil pengujian densitas

Hasil pengujian densitas menunjukkan semakin banyak campuran ampas kopi yang digunakan maka nilai densitas semakin menurun. Nilai densitas dari yang paling tinggi ke yang paling rendah berturutturut yaitu kontrol, 70/30, 60/40, 50/50, 40/60 dan $30 / 70$ dengan nilai densitas teori sebesar 3.16, 2.53, 2.32, 2.11, 1.90 dan 1.69 serta densitas aktual sebesar $1.74,1.33,1.09,0.96,0.86$, dan 0.73 . Nilai densitas akan menurun seiring dengan meningkatnya kandungan ampas kopi yang ditambahkan. Hal ini disebabkan karena semakin banyak ampas kopi yang digunakan maka semakin banyak porositas yang terbentuk dan menyebabkan kerapatan dari spesimen semakin berkurang.

Hasil penelitian dari Khalil [4] juga menyatakan bahwa nilai densitas akan menurun seiring dengan menurunnya kandungan hidroksiapatit yang ditambahkan.

\section{Hasil pengujian porositas}

Hasil pengujian densitas menunjukkan persentase porositas yang terkandung dalam sampel. persentase porositas diperoleh dari perhitungan densitas aktual dan densitas teoritis sampel BHA/ampas kopi/shellac setelah proses sintering. Persentase porositas daritiap variasi campuran dapat dilihat pada Gambar 2. 


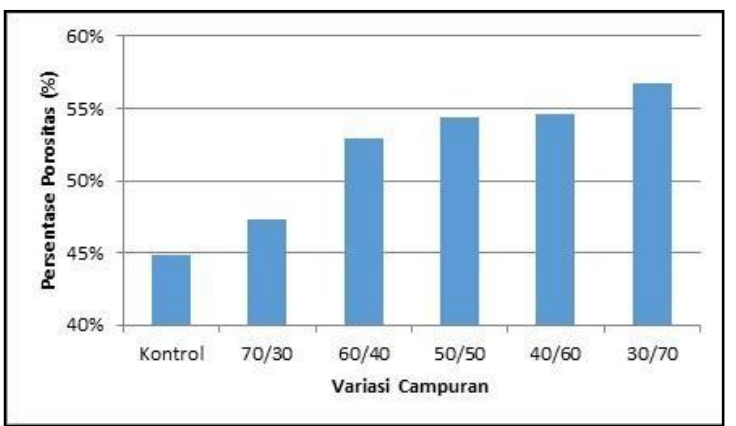

Gambar 2 Hasil pengujian porositas

Hasil pengujian porositas menunjukkan semakin banyak campuran ampas kopi yang digunakan maka persentase porositas semakin meningkat. Persentase porositas dari yang paling rendah ke yang paling tinggi berturut-turut yaitu kontrol, 70/30, 60/40, 50/50, 40/60 dan 30/70 dengan persentase porositas sebesar 45\%, 47\%, 53\%, 54\%, 55\% dan 57\%. Terbentuknya porositas disebabkan oleh kandungan ampas kopi dan shellac yang bereaksi dengan oksigen ketika proses sintering sehingga berubah menjadi gas dan menguap.

Hasil penelitian dari Wattanutchariya dan Changkowchai [5] juga menyatakan bahwa persentase porositas dari HA scaffold yang dicampur dengan chitosan dan gelatin (campuran pembentuk pori) akan meningkat dengan menurunnya konsentrasi dari HA scaffold serta meningkatnya konsentrasi dari chitosan dan gelatin.

\section{Hasil pengamatan foto SEM}

Hasil pengamatan foto SEM memperlihatkan bentuk porositas dari variasi sampel yang diperoleh dari sampel BHA/ampas kopi/shellac setelah proses sintering. Hasil foto SEM dapat dilihat pada Gambar 3 dan Gambar 4.
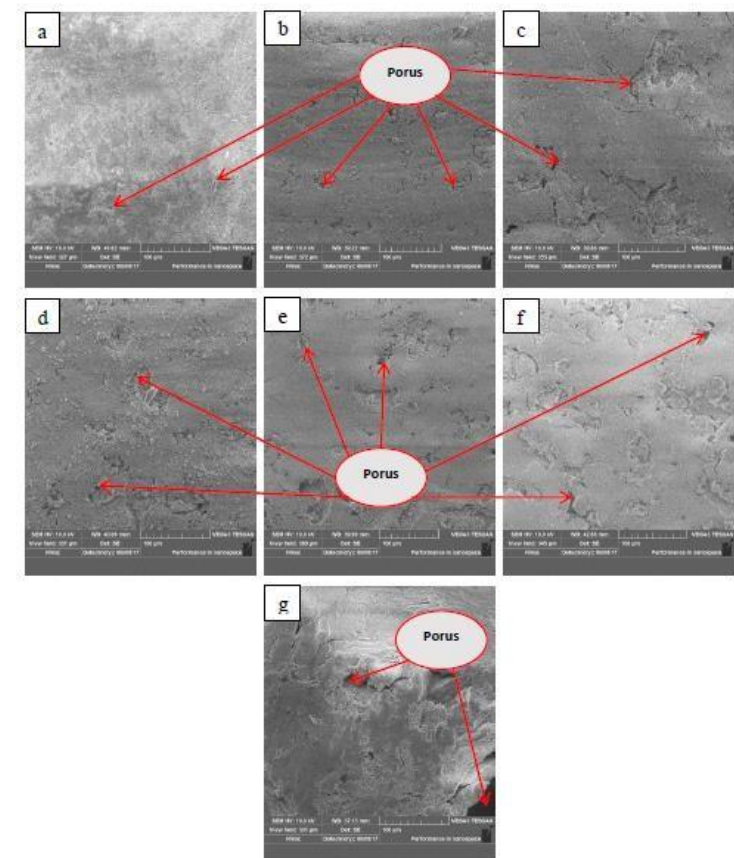

Gambar 3 Foto SEM perbesaran 100x
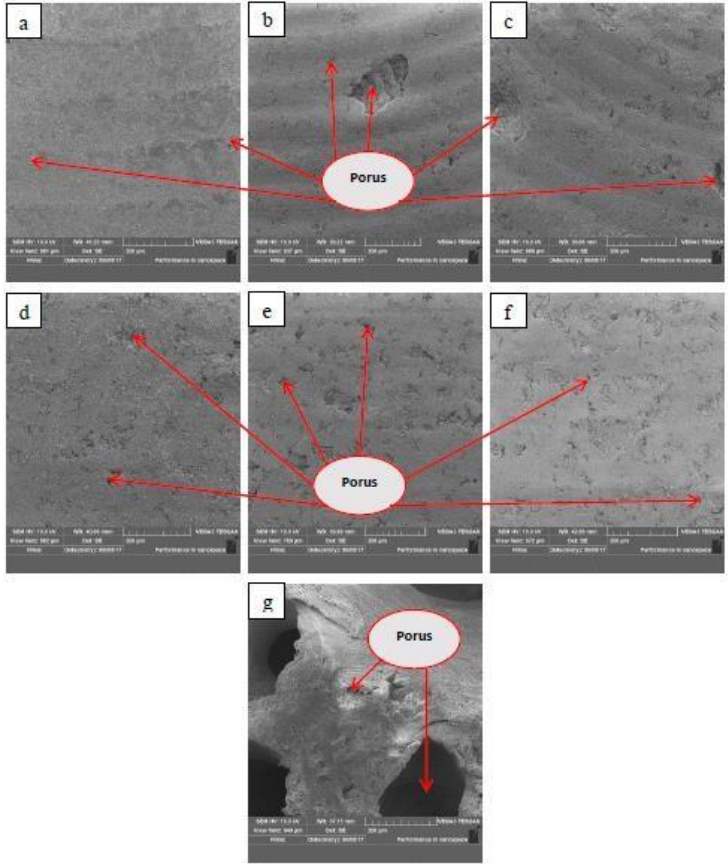

Gambar 4 Foto SEM perbesaran 200x

Keterangan Gambar 3 dan Gambar 4 yaitu:

a. BHA kontrol

b. BHA/ampas kopi/shellac 70/30

c. BHA/ampas kopi/shellac $60 / 40$

d. BHA/ampas kopi/shellac 50/50

e. BHA/ampas kopi/shellac 40/60

f. BHA/ampas kopi/shellac 30/70

g. HA komersil 
Hasil pengamatan foto SEM menunjukkan terbentuknya porositas pada BHA/ampas kopi/shellac dengan variasi 70/30, 60/40, 50/50, 40/60 dan 30/70. Pada proses sintering terjadi pertumbuhan bulir yang disebabkan serbuk-serbuk BHA yang mencair sebagian dan saling mengikat ketika dipanaskan sampai suhu $1000^{\circ} \mathrm{C}$ kemudian menjadi keras ketika didinginkan sampai suhu ruangan $\left(27^{\circ} \mathrm{C}\right)$. Pembentukan porus disebabkan oleh kandungan ampas kopi dan shellac yang bereaksi dengan oksigen ketika proses sintering sehingga berubah menjadi fasa gas dan menguap, hal ini menyebabkan terbentuknya rongga diantara serbuk BHA.

Hasil pengamatan foto SEM juga memperlihatkan porositas yang terbentuk tidak beraturan dan tidak merata serta semakin banyak campuran ampas kopi yang digunakan maka semakin banyak porositas yang terlihat. Pada BHA kontrol porus tidak terlalu terlihat hal ini disebabkan karena tidak adanya material pembentuk porus. Sedangkan bila dibandingkan dengan HA komersil, porus pada HA komersil terlihat sangat besar ini disebabkan karena pada HA komersil tulang sapi yang digunakan tidak dijadikan bentuk serbuk terlebih dahulu dan masih banyak terkandung unsur-unsur organik sehingga ketika dilakukan proses sintering bahan-bahan organik menghilang dan membentuk porus.

\section{Hasil pengamatan SEM EDX}

Hasil pengamatan SEM EDX menunjukkan unsur-unsur yang terkandung dalam sampel sampel BHA murni, BHA/ampas kopi/shellac sebelum proses sintering dan BHA/ampas kopi/shellac setelah proses sintering. Hasil SEM EDX dapat dilihat pada Gambar 5, Gambar 6 dan Gambar 7.

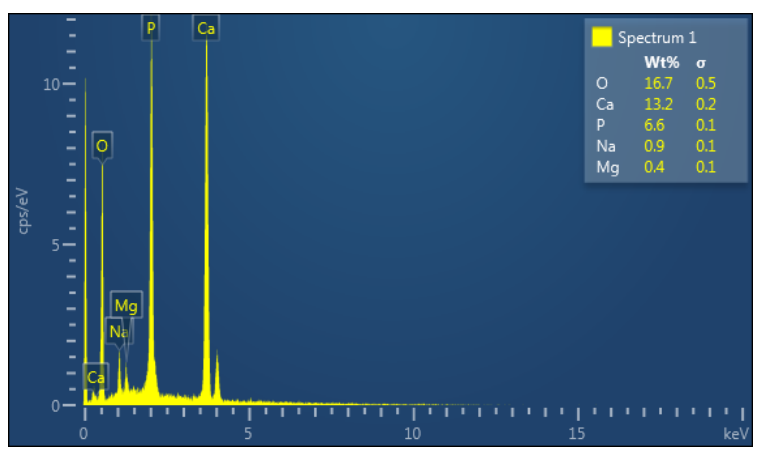

Gambar 5. SEM EDX BHA murni

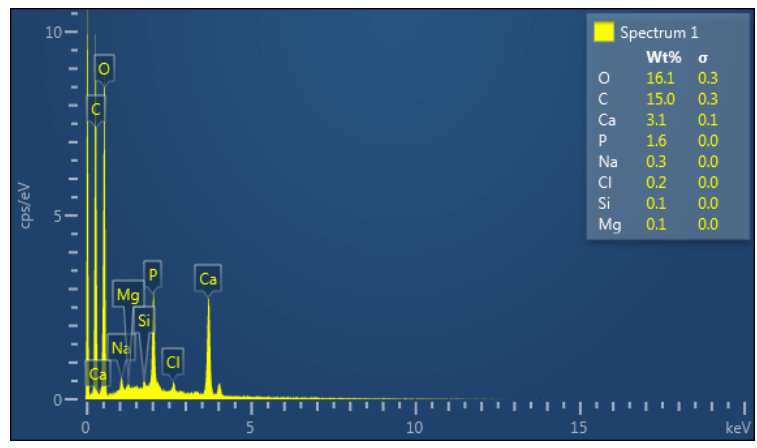

Gambar 6. SEM EDX BHA/ampas kopi/shellac sebelum disinter

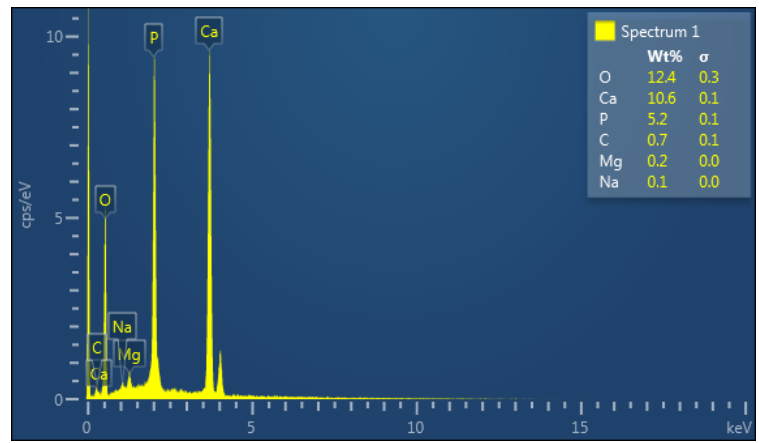

Gambar 7. SEM EDX BHA/ampas kopi/shellac sebelum disinter

Hasil spektrum EDX BHA murni (Gambar 5) menunjukkan adanya unsur-unsur anorganik pembentuk BHA yang terdiri dari Ca 13,2\%; P 6,6\%; dan O 16,7\% sebagai unsur utama serta beberapa unsur dengan intensitas yang rendah yaitu $\mathrm{Na} 0,9 \%$ dan Mg 0,4\%. Pada BHA/ampas kopi/shellac sebelum proses sintering (Gambar 6) menunjukkan unsur anorganik $\mathrm{Ca} 3,1 \%$; P 1,6\%; O 16,1\% dan beberapa unsur dengan intensitas rendah yaitu $\mathrm{Na} 0,3 \% ; \mathrm{Cl}$ $0,2 \%$; Si $0,1 \%$ dan $\mathrm{Mg} \mathrm{0,1 \%}$ serta adanya unsur $\mathrm{C}$ $15 \%$ yang menunjukkan adanya kandungan dari material pembentuk porus yaitu ampas kopi. Pada BHA/ampas kopi/shellac setelah proses sintering (Gambar 7) menunjukkan unsur anorganik $\mathrm{Ca} 10,6 \%$; $\mathrm{P} 5,2 \%$ dan $\mathrm{O} 12,4 \%$ serta beberapa unsur dengan intensitas rendah yaitu $\mathrm{C} 0,7 \% ; \mathrm{Mg} 0,2 \%$ dan $\mathrm{Na}$ $0,1 \%$. Hasil ini menunjukkan bahwa pada BHA murni tidak terdapat kandungan lain selain $\mathrm{BHA}(\mathrm{Ca}, \mathrm{P}, \mathrm{O}$, $\mathrm{Na}$ dan $\mathrm{Mg}$ ) dan ketika dicampur dengan ampas kopi dan shellac menunjukkan adanya kandungan selain BHA yaitu $\mathrm{C}, \mathrm{Cl}$ dan $\mathrm{Si}$ sedangkan ketika dilakukan proses sintering kandungan ampas kopi dan shellac $\left(\mathrm{C}, \mathrm{Cl}\right.$ dan $\mathrm{Si}$ ) bereaksi dengan $\mathrm{O}_{2}$ sehingga membentuk fasa gas dan menyebabkan kandungan ampas kopi dan shellac menguap dan menghilang.

Hasil penelitian dari Ooidkk [6] juga menyatakan bahwa spektrum EDX dari BHA yang dipanaskan sampai suhu $900^{\circ} \mathrm{C}$ menunjukkan adanya unsur anorganik berupa $\mathrm{Ca}$ dan $\mathrm{P}$ dengan intensitas tinggi serta $\mathrm{Na}, \mathrm{Mg}, \mathrm{O}$ dan $\mathrm{C}$ dengan intensitas rendah. 


\section{Hasil pengamatan laju degradasi}

Hasil pengamatan laju degradasi menunjukkan penurunan berat sampel BHA/ampas kopi/shellac setelah proses sintering yang direndam pada larutan PBS (Phospat Buffered Saline) selama 8 minggu. Penurunan berat sampel dapat dilihat pada Gambar 8 .

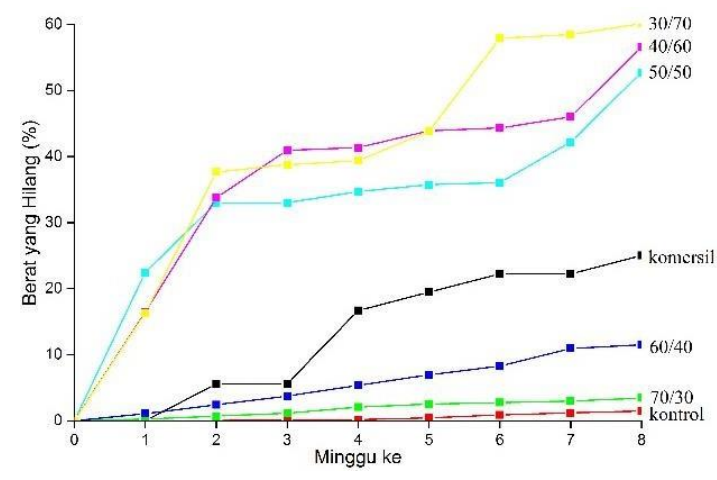

Gambar 8 Laju degradasi selama 8 minggu

Dari Gambar 8 dapat dilihat bahwa semua jenis sampel memiliki sifat biodegradable dan selama 8 minggu mengalami penurunan berat yang berbedabeda. Biodegradable masing-masing dari yang paling lambat ke yang paling cepat berturut-turut yaitu 70/30, 60/40, 50/50, 40/60 dan 30/70. Dapat dilihat bahwa semakin banyak variasi campuran dari ampas kopi maka kemampuan degradasi dari material semakin cepat. Kemampuan degradasi ini dipengaruhi oleh semakin banyaknya variasi campuran maka persentase porositas semakin meningkat dan kerapatan semakin menurun sehingga menyebabkan semakin luasnya permukaan dari spesimen yang bersentuhan dengan larutan PBS.

Variasi sampel dibandingkan dengan HA komersil dan BHA kontrol. Laju degradasi menunjukkan sampel 30/70, 40/60 dan 50/50 lebih cepat terdegradasi hal ini disebabkan ketika proses perendaman dan pengambilan berat sampel ada sebagian sampel yang mulai hancur sehingga berat yang hilang lebih banyak dari sampel 60/40 dan $70 / 30$. Sedangkan pada sampel 60/40 dan 70/30 membutuhkan waktu lebih lama untuk terdegradasi. BHA kontrol memiliki waktu degradasi paling lama dari semua variasi sampel hal ini disebabkan karena pada BHA kontrol tidak terdapat campuran ampas kopi pembentuk porus sehingga larutan PBS yang bersentuhan dengan permukaan spesimen semakin sedikit, dan jika dibandingkan dengan HA komersil, BHA kontrol lebih lama untuk terdegradasi karena HA komersil memiliki persentase porositas yang lebih besar.

Hasil penelitian dari Wattanutchariya dan Changkowchai [5] juga menyatakan bahwa kemampuan degradasi dari HA scaffold yang dicampur dengan chitosan dan gelatin (campuran pembentuk pori) akan menurun dengan meningkatnya konsentrasi dari HA scaffold serta menurunnya konsentrasi dari chitosan dan gelatin.

\section{Hasil pengamatan pola difraksi XRD}

Hasil pengamatan pola difraksi XRD menunjukkan puncak-puncak dari fasa kristalin HA. Pola difraksi XRD diperoleh dari sampel BHA murni, BHA/ampas kopi/shellac setelah proses sintering yang dibandingkan dengan standard HA JCPDS 9432. Pola difraksi dari masing-masing sampel dapat dilihat pada Gambar 9, Gambar 10, dan Gambar 11.

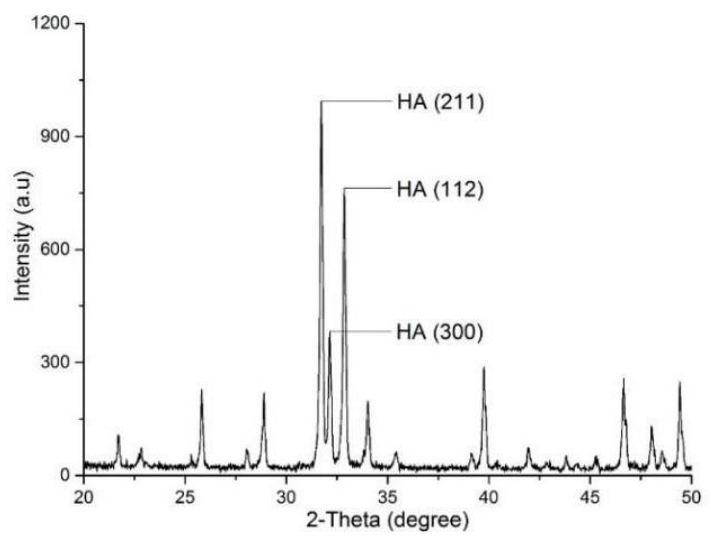

Gambar 9 Pola difraksi XRD BHA murni

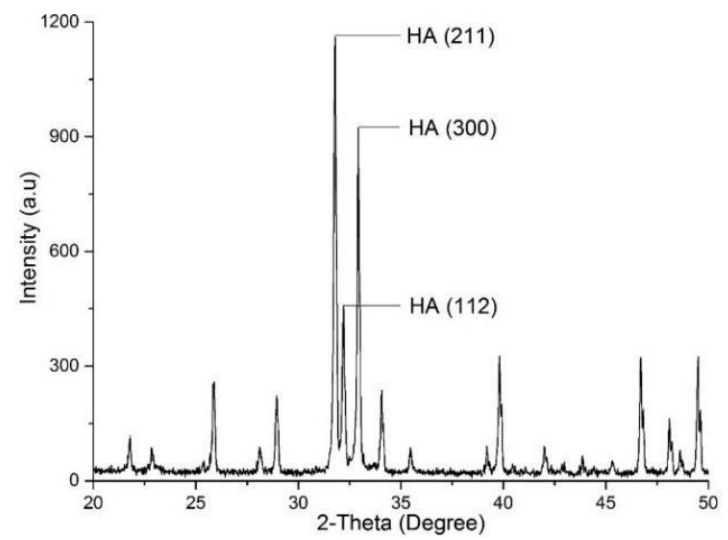

Gambar 10 Pola difraksi BHA/ampas kopi/shellac

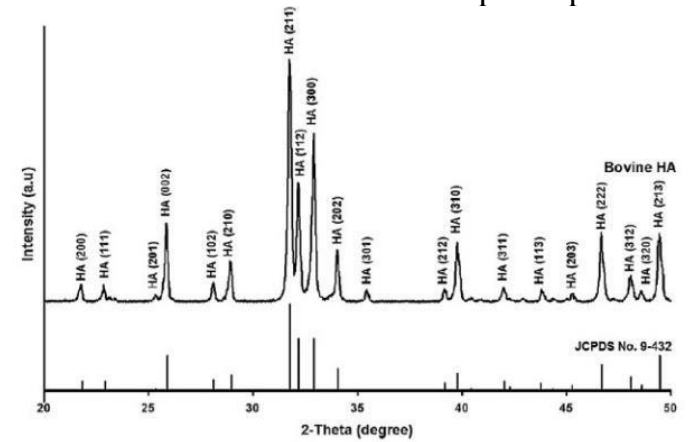

Gambar 11 Pola difraksi XRD standard HA JCPDS 9-432 
Pola difraksi dari BHA murni dan BHA/ampas kopi/shellac memiliki titik puncak dan intensitas yang hampir sama dengan standard HA JCPDS 9-432. Perbandingan titik puncak tertinggi dari BHA murni, BHA/ampas kopi/shellac dan HA JCPDS 9-432 dapat dilihat pada Tabel 1.

Tabel 1 Perbandingan titik puncak tertinggi dari BHA murni, BHA/ampas kopi/shellac dan HA JCPDS 9-432

\begin{tabular}{|c|c|c|c|c|c|c|}
\hline \multicolumn{2}{|c|}{ BHA murni } & \multicolumn{2}{|c|}{$\begin{array}{c}\text { BHA/ampas } \\
\text { kopi/shellac }\end{array}$} & \multicolumn{2}{|c|}{ HA JCPDS 9-432 } & \multirow{2}{*}{$\begin{array}{c}\text { Peaks } \\
\text { (bidang } \\
\text { geser) }\end{array}$} \\
\hline $2 \theta\left(^{\circ}\right)$ & $\mathrm{d}(\mathrm{A})$ & $2 \theta\left(^{\circ}\right)$ & $\mathrm{d}(\mathrm{A})$ & $2 \theta\left(^{\circ}\right)$ & $\mathrm{d}(\mathrm{A})$ & \\
\hline 31,753 & 2,816 & 31,811 & 2,811 & 31,773 & 2,814 & HA (211) \\
32,170 & 2,780 & 32,221 & 2,776 & 32,196 & 2,778 & HA (112) \\
32,887 & 2,721 & 32,949 & 2,716 & 32,902 & 2,720 & HA (300) \\
\hline
\end{tabular}

Pola difraksi BHA murni dikonfirmasi dengan pola difraksi standard HA JCPDS 9-432. Pola difraksi BHA murni menghasilkan intensitas tertinggi pada nilai $2 \theta: 31.753^{\circ}, 32.170^{\circ}, 32.887^{\circ}$. Jika

dibandingkan dengan intensitas tertinggi dari standard HA JCPDS 9-432 yang mempunyai nilai $20: 31.773^{\circ}$, $32.196^{\circ}, 32.902^{\circ}$ maka bisa dikatakan BHA murni telah menjadi hidroksiapatit (HA).

Hasil penelitian Herliansyah dkk [7] juga menyatakan bahwa pola difraksi XRD dari serbuk BHA yang dipanaskan $900^{\circ} \mathrm{C}$ dengan kenaikan temperatur $5^{\circ} \mathrm{C}$ menit dan penahanan temperatur selama 2 jam menunjukkan intensitas tertinggi pada nilai 20: $31.760^{\circ}, 32.160^{\circ}, 32.900^{\circ}$.

Pada Pola difraksi BHA/ampas kopi/shellac menghasilkan intensitas tertinggi pada nilai 20: $31.8111^{\circ}$, $32.9493^{\circ}, 32.2207^{\circ}$. Jika dibandingkan
dengan pola difraksi BHA murni, HA JCPDS 9-432 dan penelitian Herliansyah dkk [7] maka bisa dikatakan bahwa kandungan dari ampas kopi dan shellac telah mengalami penghilangan secara sempurna ketika BHA/ampas kopi/shellac disinter dengan suhu $1000^{\circ} \mathrm{C}$.

\section{Hasil pengamatan gugus fungsi FTIR}

Hasil pengamatan gugus fungsi FTIR menunjukkan kandungan gugus fungsi yang terkandung dalam HA. Gugus fungsi FTIR diperoleh dari sampel BHA murni dan BHA/ampas kopi/shellac setelah proses sintering. Spektrum hasil uji FTIR dapat dilihat pada Gambar 12 dan ditabelkan pada Tabel 2.

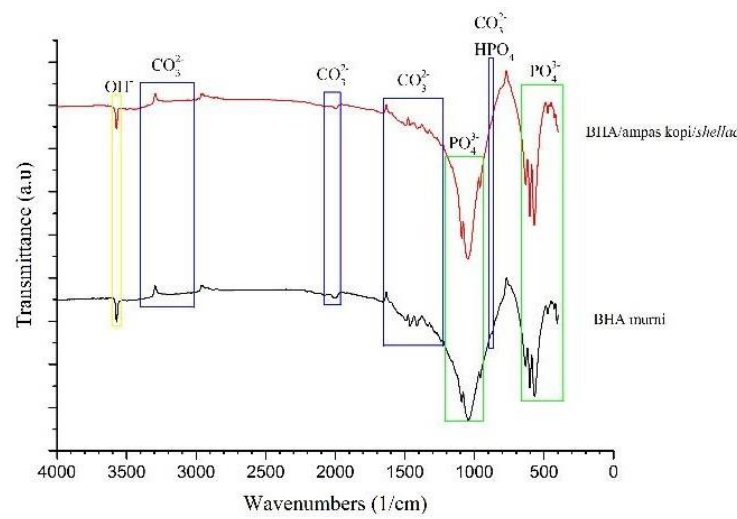

Gambar 17. Spektrum gugus fungsi BHA murni dan BHA/ampas kopi/shellac.

Tabel 2. Spektrum hasil uji FTIR BHA murni dan BHA/ampas kopi/shellac

\begin{tabular}{|c|c|c|}
\hline \multirow{2}{*}{ Gugus } & \multicolumn{2}{|c|}{ Wavenumbers $(1 / \mathrm{cm})$} \\
\hline & BHA murni & BHA/ampas kopi/shellac \\
\hline v1 $\mathrm{PO}_{4}^{3-}$ & 958.66 & 959.63 \\
\hline $\mathrm{v}_{2} \mathrm{PO}_{4}^{3-}$ & 473.54 & 473.54 \\
\hline v3 $\mathrm{PO}_{4}^{3-}$ & $1091.76 ; 1044.5$ & $1090.79 ; 1047.39$ \\
\hline $\mathrm{v}_{4} \mathrm{PO}_{4}^{3-}$ & $632.68 ; 601.82 ; 568.06$ & $632.68 ; 601.82 ; 569.99$ \\
\hline $\mathrm{v}_{3} \mathrm{CO}_{3}^{2-}$ & $\begin{array}{lcc}3427.65 ; & 3002.65 ; & 2077.42 ; \\
1989.66 ; & 1654.03 ; & 1601.95 ; \\
1546.01 ; & 1492 ; & 1463.07 ; \\
1412.92 ; & 1333.83 ; & 1239.32 ; \\
1288.5 ; & & \end{array}$ & $\begin{array}{l}3436.33 ; 1494.9 ; 1410.99 ; \\
1333.83 ; 1239,32\end{array}$ \\
\hline $\mathrm{v}_{2} \mathrm{CO}_{3}^{2-}$ & 875.72 & - \\
\hline $\mathrm{OH}^{-}$ & 3571.36 & 3572.32 \\
\hline
\end{tabular}

Spektrum FTIR BHA murni menunjukkan adanya tiga titik puncak utama yang berupa gugus fungsi fosfat $\left(\mathrm{PO}_{4}^{3-}\right)$, karbonat $\left(\mathrm{CO}_{3}^{2-}\right)$ dan hidroksil $\left(\mathrm{OH}^{-}\right)$.

Hasil penelitian Rehman dan Bonfield [8] yang meneliti tentang HA sintesis dan 5 HA komersil berbeda menunjukkan hasil dengan titik vibrasi yang sama yaitu:

1. Gugus fungsi $\mathrm{PO}_{4}^{3-}$ mempunyai empat titik vibrasi, yaitu vibrasi simetri stretching $\left(\mathrm{v}_{1}\right)$ dengan bilangan gelombang sekitar $961 \mathrm{~cm}^{-1}$, vibrasi simetri bending $\left(\mathrm{v}_{2}\right)$ dengan bilangan gelombang sekitar $475-440 \mathrm{~cm}^{-1}$, vibrasi asimetri stretching $\left(\mathrm{v}_{3}\right)$ dengan bilangan gelombang sekitar 1190-976 $\mathrm{cm}^{-1}$ dan vibrasi asimetri bending $\left(\mathrm{v}_{1}\right)$ dengan bilangan gelombang sekitar $660-520 \mathrm{~cm}^{-1}$.

2. Gugus fungsi $\mathrm{CO}_{3}^{2-}$ mempunyai dua titik vibrasi, yaitu sekitar $1650-1300 \mathrm{~cm}^{-1}$, dan sekitar $875 \mathrm{~cm}^{-}$ 1. Pada titik $875 \mathrm{~cm}^{-1}$ selain menunjukkan gugus fungsi $\mathrm{CO}_{3}^{2}-$ juga menunjukkan gugus fungsi $\mathrm{HPO}_{4}^{2-}$.

3. Gugus fungsi $\mathrm{OH}^{-}$terletak pada bilangan gelombang $3569 \mathrm{~cm}^{-1}$.

Pada gugus fungsi spektrum FTIR BHA/ampas kopi/shellac menunjukkan gugus fungsi fosfat 
tidak adanya puncak utama yang terlihat. Jika dibandingkan dengan gugus fungsi BHA murni dan penelitian Rehman dan Bonfield [8] maka bisa dikatakan bahwa kandungan dari shellac dan ampas kopi benar-benar menghilang secara sempurna ketika proses sintering dengan suhu $1000^{\circ} \mathrm{C}$ dan yang tersisa hanya hidroksiapatit.

\section{KESIMPULAN}

Berdasarkan proses pengujian, pengamatan serta hasil pembahasan yang telah dilakukan dalam penelitian dapat diambil kesimpulan sebagai berikut:

1. Pengujian densitas dan porositas menunjukkan semakin banyak campuran ampas kopi yang digunakan maka nilai densitas semakin menurun dan persentase porositas semakin meningkat.

2. Pengamatan foto SEM memperlihatkan terbentuknya porus pada BHA/ampas kopi/shellac dengan variasi 70/30,60/40, 50/50, 40/60, dan $30 / 70$. Porus yang terbentuk tidak beraturan dan tidak merata serta semakin banyak campuran ampas kopi yang digunakan maka semakin banyak porositas yang terihat. Pada pengamatan SEM EDX menunjukkan adanya unsur anorganik berupa $\mathrm{Ca}$ dan $\mathrm{P}$ dengan intensitas tinggi serta $\mathrm{Na}$, $\mathrm{Mg}, \mathrm{O}$ dan $\mathrm{C}$ dengan intensitas rendah.

3. Pengamatan laju degradasi menunjukkan bahwa semua jenis variasi sampel bersifat biodegradable dan semakin banyak campuran ampas kopi yang digunakan maka semakin cepat sampel untuk terdegradasi. Laju degradasi dari yang paling cepat ke yang paling lambat berturut-turut yaitu 30/70, 40/60, 50/50, 40/60 dan 70/30.

4. Pengamatan pola difraksi XRD menunjukkan BHA/ampas kopi/shellac sebagai fasa kemurnian dari hidroksiapatit (HA). Nilai $2 \theta$ untuk senyawa HA sesuai dengan pola difraksi standar HA JCPDS 9-432. Maka bisa dikatakan bahwa kandungan dari ampas kopi dan shellac telah menghilang secara sempurna setelah proses sintering sampai suhu $1000^{\circ} \mathrm{C}$.

5. Analisa gugus fungsi dengan FTIR menunjukkan BHA/ampas kopi/shellac memiliki tiga titik puncak utama yang berupa gugus fungsi fosfat $\left(\mathrm{PO}^{3-}\right)$, karbonat $\left(\mathrm{CO}^{2-}\right)$ dan hidroksil $\left(\mathrm{OH}^{-}\right)$.

Tidak adanya puncak utama lain, menunjukkan bahwa kandungan dari shellac dan ampas kopi telah menghilang secara sempurna setelah proses sintering sampai suhu $1000^{\circ} \mathrm{C}$ dan yang tersisa hanya hidroksiapatit (HA).

\section{DAFTAR PUSTAKA}

[1] E. Kusrini, M. Sontang, "Characterization of X- Ray Diffraction and Electron Spin Resonance: Effects of Sintering Time and Temperature on Bovine Hydroxyapatite,' Radiat. Phys. Chem. vol. 81, pp. 118-125, 2012

doi:10.1016/j.radphyschem.2011.10.006.
[2] L. R. S. J. Park, "Biomaterials, Springer," New York, 2007. doi:10.1007/978-0-38737880-0.

[3] E. Tamariz, A. Rios-Ramrez, "Biodegradation of Medical Purpose Polymeric Materials and Their Impact on Biocompatibility," Biodegrad. - Life Sci., InTech, pp. 1-16, 2013. doi: $10.5772 / 56220$.

[4] K.A. Khalil, "A New-Developed Nanostructured Mg / HAp Nanocomposite by High Frequency Induction Heat Sintering Process," Int. J. Electrochem. Sci. vol. 7, pp. 10698-10710, 2012.

[5] W. Wattanutchariya, W. Changkowchai, "Characterization of Porous Scaffold from Chitosan - Gelatin / Hydroxyapatite for Bone Grafting," Proc. Int. MultiConference Eng. Comput. Sci. II, 2014.

[6] C.Y. Ooi, M. Hamdi, S. Ramesh, "Properties of Hydroxyapatite Produced by Annealing of Bovine Bone," Ceram. Int. vol. 33, pp. 11711177 , 2007. doi:10.1016/j.ceramint.2006.04.001.

[7] M.K. Herliansyah, M. Hamdi, A. IdeEktessabi, M.W. Wildan, J.A. Toque, "The Influence of Sintering Temperature on the Properties of Compacted Bovine hydroxyapatite," Mater. Sci. Eng. C. vol. 29, pp. $1674-1680 . \quad 2009$. doi:10.1016/j.msec.2009.01.007.

[8] I. Rehman, W. Bonfield, "Characterization of Hydroxyapatite and Carbonated Apatite by Photo Acoustic FTIR Spectroscopy," J. Mater. Sci. Mater. Med. vol. 8, pp. 1-4, 1997. doi:10.1023/A:1018570213546. 